\title{
Controlling Regiochemistry of Zirconocene-Catalyzed Hydrosilation of Styrenes. Selective Preparation of Markovnikov and anti-Markovnikov Addition Products Using Same Combination of Procatalysts
}

\author{
Yasuyuki Ura, Guohua Gao, Fengyu Bao, Masamichi Ogasawara, and Tamotsu Takahashi* \\ Catalysis Research Center and Graduate School of Pharmaceutical Sciences, Hokkaido \\ University, and SORST, Japan Science and Technology Agency (JST), Kita-ku, Sapporo 001- \\ 0021, Japan
}

\section{Supporting Information}

\section{Experimental Section}

General. All anaerobic and/or moisture sensitive manipulations were carried out with standard Schlenk techniques under predried nitrogen. NMR spectra were recorded on a JEOL JNM AL-300 spectrometer $\left({ }^{1} \mathrm{H}, 300 \mathrm{MHz} ;{ }^{13} \mathrm{C}, 75 \mathrm{MHz}\right) .{ }^{1} \mathrm{H}$ and ${ }^{13} \mathrm{C}$ chemical shifts are reported in ppm downfield of internal tetramethylsilane. Tetrahydrofuran was distilled from benzophenone-ketyl prior to use. All the other chemicals were obtained from commercial sources and used without further purification.

Zirconocene-Catalyzed Markovnikov Hydrosilation of Styrenes. The reaction conditions and results are summarized in Table 1 and Table 2. A typical procedure is given for the preparation of diphenyl(1-phenylethyl)silane (4a): To a solution of $\mathrm{Cp}_{2} \mathrm{ZrCl}_{2}(58 \mathrm{mg}, 0.20$ $\mathrm{mmol})$ in THF $(5 \mathrm{~mL})$ was added $n$-BuLi hexane solution $(1.6 \mathrm{~mol} / \mathrm{L}, 0.38 \mathrm{~mL}, 0.60 \mathrm{mmol})$ at $78{ }^{\circ} \mathrm{C}$. After stirring the solution for $1 \mathrm{~h}$ at this temperature, diphenylsilane $(\mathbf{2 a} ; 220 \mathrm{mg}, 1.2$ $\mathrm{mmol})$ and styrene $(\mathbf{1 a} ; 114 \mu \mathrm{L}, 1.0 \mathrm{mmol})$ were added in this order. The reaction mixture was warmed to room temperature and stirred for $1 \mathrm{~h}$. After aqueous work-up, GC analysis of the reaction mixture showed formation of $\mathbf{4 a}$ in $98 \%$ yield (Table 1, entry 2). The silanes $\mathbf{3 a},{ }^{1} \mathbf{4 e},{ }^{2}$ $\mathbf{4 f},{ }^{3}$ and $\mathbf{4 \mathbf { g } ^ { 4 }}$ are known compounds and characterized by comparison of their ${ }^{1} \mathrm{H}$ and ${ }^{13} \mathrm{C} \mathrm{NMR}$ spectra with those reported previously. The characterization data of all the other products are listed below.

Diphenyl(1-phenylethyl)silane (4a): ${ }^{1} \mathrm{H} \mathrm{NMR}\left(300 \mathrm{MHz}, \mathrm{CDCl}_{3}\right): \delta 1.46(\mathrm{~d}, J=7.5 \mathrm{~Hz}$, $3 \mathrm{H}), 2.82(\mathrm{qd}, J=7.5$ and $3.4 \mathrm{~Hz}, 1 \mathrm{H}), 4.81(\mathrm{~d}, J=3.4 \mathrm{~Hz}, 1 \mathrm{H}), 6.99-7.53(\mathrm{~m}, 15 \mathrm{H}) .{ }^{13} \mathrm{C}\left\{{ }^{1} \mathrm{H}\right\}$ NMR $\left(75 \mathrm{MHz}, \mathrm{CDCl}_{3}\right): \delta 16.47,26.93,124.88,127.68,127.69,127.89,128.13,129.54,129.68$, 132.99, 133.00, 135.53, 135.67, 144.30. Anal. Calcd for $\mathrm{C}_{20} \mathrm{H}_{20} \mathrm{Si}$ : C, 83.28; H, 6.99. Found: $\mathrm{C}$, 83.35; H, 7.16.

[1-(4-Fluorophenyl)ethyl]diphenylsilane (4b): ${ }^{1} \mathrm{H} \mathrm{NMR}\left(300 \mathrm{MHz}, \mathrm{CDCl}_{3}\right): \delta 1.44$ (d, $J=7.5 \mathrm{~Hz}, 3 \mathrm{H}), 2.80(\mathrm{qd}, J=7.5$ and $3.4 \mathrm{~Hz}, 1 \mathrm{H}), 4.81(\mathrm{~d}, J=3.4 \mathrm{~Hz}, 1 \mathrm{H}), 6.84-6.94(\mathrm{~m}, 4 \mathrm{H})$, 7.23-7.52 (m, $10 \mathrm{H}) .{ }^{13} \mathrm{C}\left\{{ }^{1} \mathrm{H}\right\} \mathrm{NMR}\left(75 \mathrm{MHz}, \mathrm{CDCl}_{3}\right): \delta 16.65,26.17,114.86\left(\mathrm{~d}, J_{\mathrm{CF}}=21 \mathrm{~Hz}\right)$, $127.78,127.96,128.82\left(\mathrm{~d}, J_{\mathrm{CF}}=7.5 \mathrm{~Hz}\right), 129.66,129.78,132.75,135.49,135.63,139.85,139.88$, $160.63\left(\mathrm{~d}, J_{\mathrm{CF}}=242 \mathrm{~Hz}\right.$ ). Anal. Calcd for $\mathrm{C}_{20} \mathrm{H}_{19} \mathrm{FSi}$ : C, 78.39; H, 6.25. Found: C, 78.44; H, 6.32 .

[1-(4-Methylphenyl)ethyl]diphenylsilane (4c): ${ }^{1} \mathrm{H} \mathrm{NMR}\left(300 \mathrm{MHz}, \mathrm{CDCl}_{3}\right): \delta 1.43(\mathrm{~d}$, $J=7.5 \mathrm{~Hz}, 3 \mathrm{H}), 2.28(\mathrm{~s}, 3 \mathrm{H}), 2.78(\mathrm{qd}, J=7.5$ and $3.3 \mathrm{~Hz}, 1 \mathrm{H}), 4.83(\mathrm{~d}, J=3.3 \mathrm{~Hz}, 1 \mathrm{H}), 6.90(\mathrm{~d}$, 
$J=8.0 \mathrm{~Hz}, 2 \mathrm{H}), 6.99(\mathrm{~d}, J=8.0 \mathrm{~Hz}, 2 \mathrm{H}), 7.20-7.40(\mathrm{~m}, 8 \mathrm{H}), 7.52(\mathrm{dd}, J=7.8$ and $1.4 \mathrm{~Hz}, 2 \mathrm{H})$.

${ }^{13} \mathrm{C}\left\{{ }^{1} \mathrm{H}\right\} \mathrm{NMR}\left(75 \mathrm{MHz}, \mathrm{CDCl}_{3}\right): \delta 16.69,20.93,26.35,127.57,127.69,127.86,128.86,129.50$, 129.62, 133.18, 133.20, 134.21, 135.55, 135.70, 141.17. Anal. Calcd for $\mathrm{C}_{21} \mathrm{H}_{22} \mathrm{Si}: \mathrm{C}, 83.38 ; \mathrm{H}$, 7.33. Found: C, 83.48; H, 7.36.

[1-(4-Methoxyphenyl)ethyl]diphenylsilane (4d): ${ }^{1} \mathrm{H}$ NMR $\left(300 \mathrm{MHz}, \mathrm{CDCl}_{3}\right): \delta 1.43$ $(\mathrm{d}, J=7.5 \mathrm{~Hz}, 3 \mathrm{H}), 2.76(\mathrm{qd}, J=7.5$ and $3.4 \mathrm{~Hz}, 1 \mathrm{H}), 3.75(\mathrm{~s}, 3 \mathrm{H}), 4.82(\mathrm{~d}, J=3.4 \mathrm{~Hz}, 1 \mathrm{H})$, 6.72-7.58 (m, 14H). ${ }^{13} \mathrm{C}\left\{{ }^{1} \mathrm{H}\right\}$ NMR $\left(75 \mathrm{MHz}, \mathrm{CDCl}_{3}\right): \delta 16.82,25.74,55.20,113.58,127.70$, $127.88,128.52,129.51,129.64,133.12,133.16,135.55,135.68,136.25,157.04$. Anal. Calcd for $\mathrm{C}_{21} \mathrm{H}_{22} \mathrm{OSi}$ : C, 79.20; H, 6.96. Found: C, 79.27; H, 7.05.

Reaction of $\boldsymbol{n}$-BuLi with 2a. To a solution of $2 \mathbf{a}(0.297 \mathrm{ml}, 1.60 \mathrm{mmol})$ in THF (5 mL) was added $n$-BuLi in hexane $(1.60 \mathrm{~mol} / \mathrm{L}, 0.25 \mathrm{~mL}, 0.40 \mathrm{mmol})$ at $-78{ }^{\circ} \mathrm{C}$ and the solution was stirred for $1 \mathrm{~h}$ at this temperature. After aqueous work-up, GC analysis of the reaction mixture showed formation of $n-\mathrm{BuSiHPh}_{2}{ }^{5}$ in a quantitative yield. The alkylsilane was isolated as colorless oil by silica gel chromatography using hexane as an eluent. ${ }^{1} \mathrm{H}$ NMR $(300 \mathrm{MHz}$, $\left.\mathrm{CDCl}_{3}\right): \delta 0.93(\mathrm{t}, J=7.2 \mathrm{hz}, 3 \mathrm{H}), 1.17-1.23(\mathrm{~m}, 2 \mathrm{H}), 1.40-1.53(\mathrm{~m}, 4 \mathrm{H}), 4.91(\mathrm{t}, J=3.9 \mathrm{~Hz}, 1 \mathrm{H})$, 7.37-7.43 (m, 6H), 7.59-7.61 (m, 4H). ${ }^{13} \mathrm{C}\left\{{ }^{1} \mathrm{H}\right\} \mathrm{NMR}\left(75 \mathrm{MHz}, \mathrm{CDCl}_{3}\right): \delta 11.87,14.25,13.70$, 26.59, 127.93, 129.44, 134.69, 135.11. HRMS Calcd for $\mathrm{C}_{16} \mathrm{H}_{20} \mathrm{Si}: 240.1334$. Found: 240.1343 .

Hydrosilation of 1a with 2a Catalyzed by $\mathrm{Cp}_{2} \mathrm{Zr}(\boldsymbol{n} \text {-Bu })_{2} / \mathrm{LiBHEt}_{3}$. To a solution of $\mathrm{Cp}_{2} \mathrm{ZrCl}_{2}(58.4 \mathrm{mg}, 0.200 \mathrm{mmol})$ in THF $(5 \mathrm{~mL})$ was added $n$-BuLi in hexane $(1.60 \mathrm{~mol} / \mathrm{L}, 0.25$ $\mathrm{mL}, 0.40 \mathrm{mmol}$ ) at $-78{ }^{\circ} \mathrm{C}$ and the solution was stirred for $1 \mathrm{~h}$ at this temperature. A THF solution of $\mathrm{LiBHEt}_{3}(1.01 \mathrm{~mol} / \mathrm{L}, 0.20 \mathrm{ml}, 0.20 \mathrm{mmol})$ was added to this solution by means of syringe and the solution was futher stirred for $1 \mathrm{~h}$. At the same temperature, $2 \mathbf{a}(0.22 \mathrm{ml}, 1.20$ $\mathrm{mmol})$ and $1 \mathbf{a}(0.115 \mathrm{ml}, 1.00 \mathrm{mmol})$ were added subsequently. The reaction mixture was warmed to room temperature and stirred for $1 \mathrm{~h}$. After aqueous work-up, GC analysis of the reaction mixture showed formation of $\mathbf{3 a}$ in $>99 \%$ yield.

Hydrosilation of $1 \mathrm{a}$ with 2a Catalyzed by $\mathrm{Cp}_{2} \mathrm{ZrCl}_{2} / \mathbf{n}$-BuLi (3 equiv)/BEt 3 . To a solution of $\mathrm{Cp}_{2} \mathrm{ZrCl}_{2}(58.4 \mathrm{mg}, 0.200 \mathrm{mmol})$ in THF $(5 \mathrm{~mL})$ was added $n$-BuLi in hexane (1.60 $\mathrm{mol} / \mathrm{L}, 0.38 \mathrm{~mL}, 0.60 \mathrm{mmol}$ ) at $-78{ }^{\circ} \mathrm{C}$ and the solution was stirred for $1 \mathrm{~h}$ at this temperature. A THF solution of $\mathrm{BEt}_{3}(1.00 \mathrm{~mol} / \mathrm{L}, 0.20 \mathrm{ml}, 0.20 \mathrm{mmol})$ was added to this solution by means of syringe and the solution was futher stirred for $1 \mathrm{~h}$. At the same temperature, $2 \mathbf{a}(0.22 \mathrm{ml}, 1.20$ $\mathrm{mmol})$ and $\mathbf{1 a}(0.115 \mathrm{ml}, 1.00 \mathrm{mmol})$ were added subsequently. The reaction mixture was warmed to room temperature and stirred for $1 \mathrm{~h}$. After aqueous work-up, GC analysis of the reaction mixture showed formation of $\mathbf{3 a}$ in $>99 \%$ yield.

Hydrosilation of 1 a with $2 \mathrm{a}$ Catalyzed by $\mathrm{Cp}_{2} \mathrm{Zr}(\mathrm{H}) \mathrm{Cl} / \boldsymbol{n}$-BuLi (2 equiv). To a solution of $\mathrm{Cp}_{2} \mathrm{Zr}(\mathrm{H}) \mathrm{Cl}(51.6 \mathrm{mg}, 0.200 \mathrm{mmol})$ in THF $(5 \mathrm{~mL})$ was added $n$-BuLi in hexane (1.60 $\mathrm{mol} / \mathrm{L}, 0.25 \mathrm{~mL}, 0.40 \mathrm{mmol})$ at $-78{ }^{\circ} \mathrm{C}$ and the solution was stirred for $1 \mathrm{~h}$ at this temperature. At the same temperature, $\mathbf{2 a}(0.22 \mathrm{ml}, 1.20 \mathrm{mmol})$ and $\mathbf{1 a}(0.115 \mathrm{ml}, 1.00 \mathrm{mmol})$ were added subsequently. The reaction mixture was warmed to room temperature and stirred for $1 \mathrm{~h}$. After aqueous work-up, GC analysis showed exclusive formation of $\mathbf{4 a}$, which was isolated in $90 \%$ yield by silica gel chromatography.

Hydrosilation of 1 a with 2a Catalyzed by $\mathrm{Cp}_{2} \mathrm{Zr}(\mathrm{H}) \mathrm{Cl} / \boldsymbol{n}$-BuLi (1 equiv). To a solution of $\mathrm{Cp}_{2} \mathrm{Zr}(\mathrm{H}) \mathrm{Cl}(51.6 \mathrm{mg}, 0.200 \mathrm{mmol})$ in THF $(5 \mathrm{~mL})$ was added $n$-BuLi in hexane (1.60 $\mathrm{mol} / \mathrm{L}, 0.13 \mathrm{~mL}, 0.20 \mathrm{mmol}$ ) at $-78{ }^{\circ} \mathrm{C}$ and the solution was stirred for $1 \mathrm{~h}$ at this temperature. At 
the same temperature, $\mathbf{2 a}(0.22 \mathrm{ml}, 1.20 \mathrm{mmol})$ and $\mathbf{1 a}(0.115 \mathrm{ml}, 1.00 \mathrm{mmol})$ were added subsequently. The reaction mixture was warmed to room temperature and stirred for $1 \mathrm{~h}$. After aqueous work-up, GC analysis showed formation of 3a as a major product (81\%) together with a small amount of $\mathbf{4 a}(18 \%)$.

\section{References}

(1) Kesti, M. R.; Waymouth, R. M. Organometallics 1992, 11, 1095.

(2) Gountchev, T. I.; Tilley, T. D. Organometallics 1999, 18, 5661.

(3) Fu, P.-F.; Brard, L.; Li, Y.; Marks, T. J. J. Am. Chem. Soc. 1995, 117, 7157.

(4) Baba, T.; Yuasa, H.; Handa, H.; Ono, Y. Catalysis Lett. 1998, 50, 83.

(5) Fryzuk, M. D.; Rosenberg, L.; Rettig, S. J. Organometallics 1966, 15, 2871. 